Geza Katona - Janos Juhasz

\title{
THE HISTORY OF THE TRANSPORT SYSTEM DEVELOPMENT AND FUTURE WITH SHARING AND AUTONOMOUS SISTEMS
}

The world today is rapidly changing with the spread of automation. Moreover, urban life is more and more common and the number of inhabitants is rapidly growing. This time is the renaissance of bicycle-based vehicles, especially of electric power assisted bicycles. Vehicle sharing is also getting more popular. These progresses will have a crucial effect on traditional transportation networks. Moreover, the traffic volume, parking facilities and public space usage can be drastically modified. A research data is introduced from Paris and Lisbon, which helps to forecast the effect of the autonomous and sharing systems. This evolution can be advantageous, but it can also bring some disadvantages. In this article, these changes are summarized in the mirror of history, especially the Futurama concept and the transport system changes in Los Angeles. This overview will be a good basis for further research and for the development of a routing algorithm.

Keywords: smart city, multimodal, autonomous, sharing

\section{Introduction}

Autonomous development is more and more in the focus of all the developers in the transportation industry. Tesla [1] and Google [2] are the biggest from the IT sector, but conventional car builders also invested a lot in this research area. Not just the automotive sector, but train [3] and aircraft [4] manufacturing companies also take part in this improvement, and their aim is to achieve the biggest available cost savings. This can be realized by cutting down operational costs and by reducing the probability of accidents. Moreover, in the case of the rail industry the infrastructure optimization is also a key factor [5]. Furthermore, the smart city concept can also be effective and be a part of these developments. The evolution of the smart city concept was in the highlight of a study, with the intent to summarize and determine the content of the concept [6]. The outcome was that the definition is still forming, the content is expanding and 'smart city' trends cover the environmental, the digital and the social part of the life, as well. This also has an effect on Urban planning which was examined by Koryagin [7]. Moreover, the smart city conception can affect the transportation performance. These characteristics and the possible changes are also determinative [8].

In the case of a passenger transport in a multimodal transport chain, the level of comfort and available parking spots are the most important factors. This was researched and three scenarios were modeled in [9]. The three alternatives are the following: the first is traveling only with a private car; the second is that the decision can be made between using a private car or using the public transport with a $\mathrm{P}+\mathrm{R}$ facility and the third alternative considered the personal comfort additionally. This area was also examined by Kirchler [10]. The effect on the environment was also examined from the viewpoint of parking [11].

The environmental impact must be taken into account, as well, regarding the level of pollution and the resources used by the transportation. This, especially the $\mathrm{CO} 2$ emission was in the main focus of a study made at Altao University [12]. The effect on environment was also examined from the viewpoint of parking [13]. One should not forget the economic aspects [14]. Furthermore, the special case of logistics has to be taken in account, as well [15].

Regarding autonomous operation, the acceptance by the society is also a key factor. A wide range survey was made in 2014, which focused on opinion of the common people [16]. Moreover, ethical questions cannot be neglected, either [17]. Furthermore, the testing procedure is also a key factor in this case [18]. In other studies, some predictions were made to sum up the possible advantages and disadvantages of the role of autonomous transportation [19-20]. In addition, the traffic distribution need to be considered, as well [21]. With the usage of the autonomous systems, the door-to-door transport can be made easier. A review was made to summarize the accessibility of the public transport [22].

This article is an extension of a conference paper [23]. That paper focused only on the role of autonomous cars. In this article, their effect on the public transport and the possible function of autonomous vehicles in public transport is presented. One of the inspirations to widen our study was a presentation about the trends and opportunities in the future cities [24].

\section{Geza Katona*, Janos Juhasz}

Department of Automotive Technologies, Faculty of Transportation Engineering and Vehicle Engineering, Budapest University of Technology and Economics, Hungary

*E-mail of corresponding author: geza.katona@gjt.bme.hu 


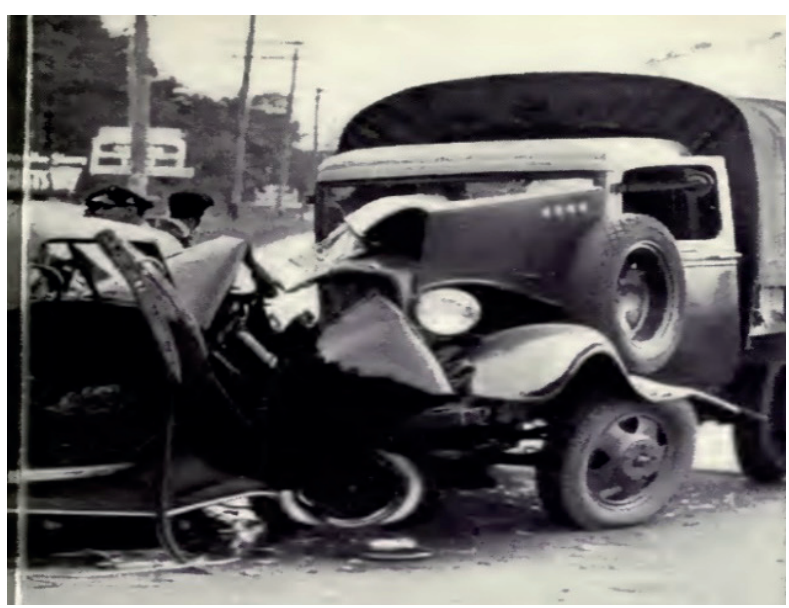

Figure 1 Safe (in the arm of Jesus) [27]

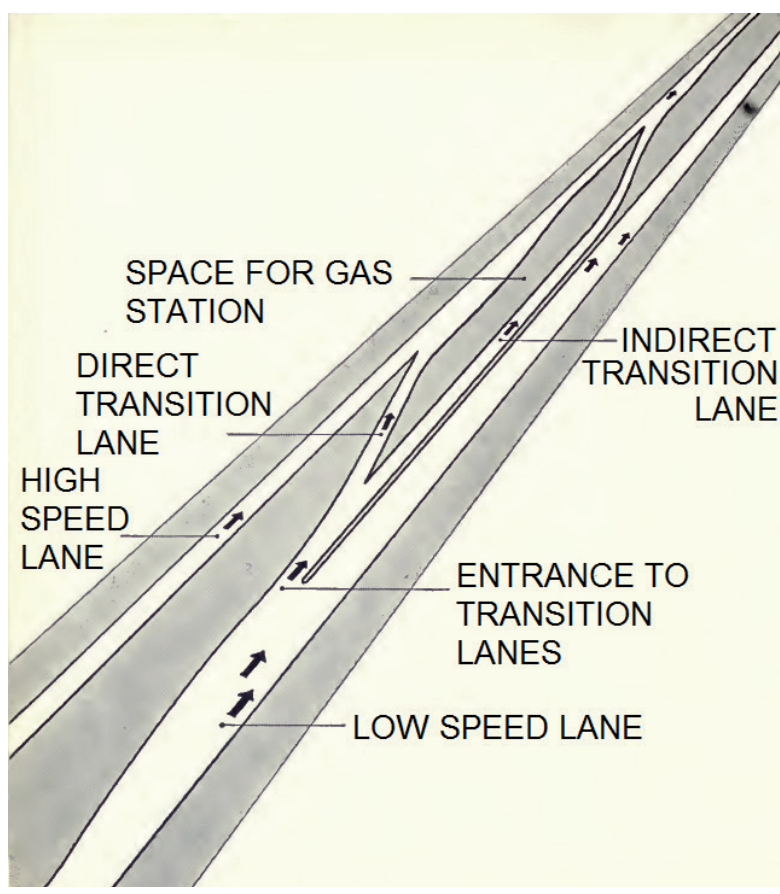

Figure 2 Transit from one speed to another [27]

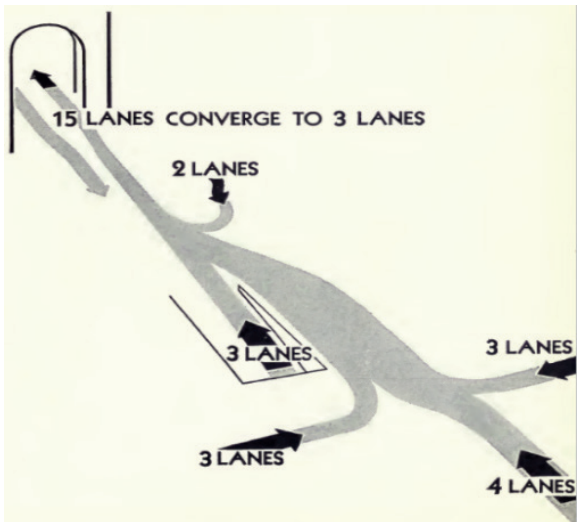

Figure 3 George Washington bridge approach problem [27]

Regarding the research listed above, there is an active discussion to find some solutions for the problems caused by urbanization. There are several possible answers, such as the smart city concept, the autonomous driving and

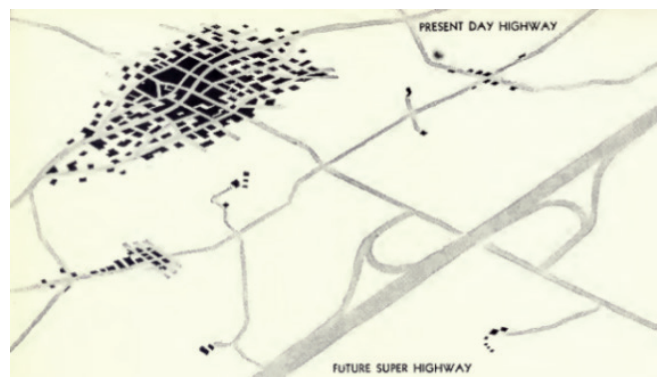

Figure 4 Motorway feeders from farm and village [27]

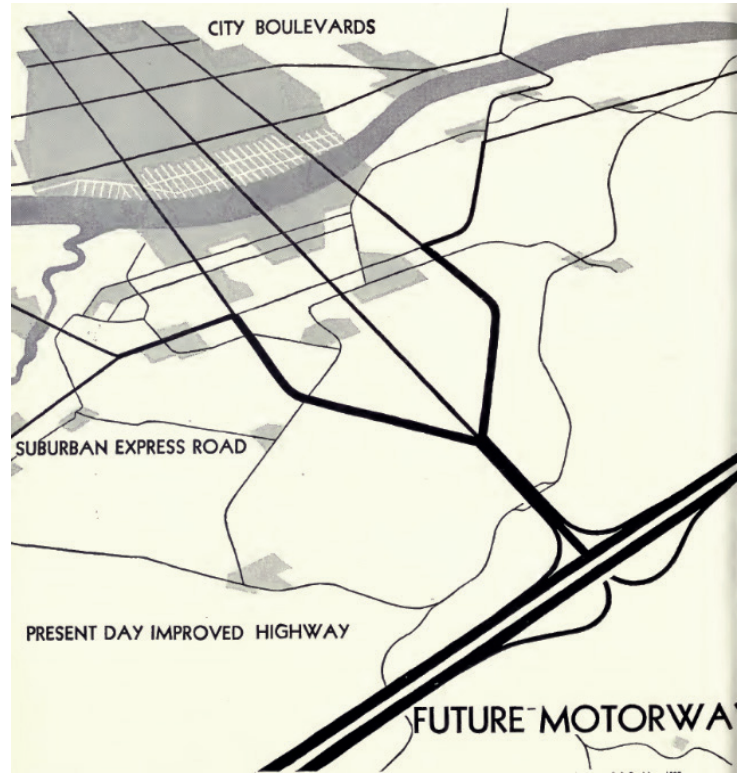

Figure 5 Motorway feeder to city [27]

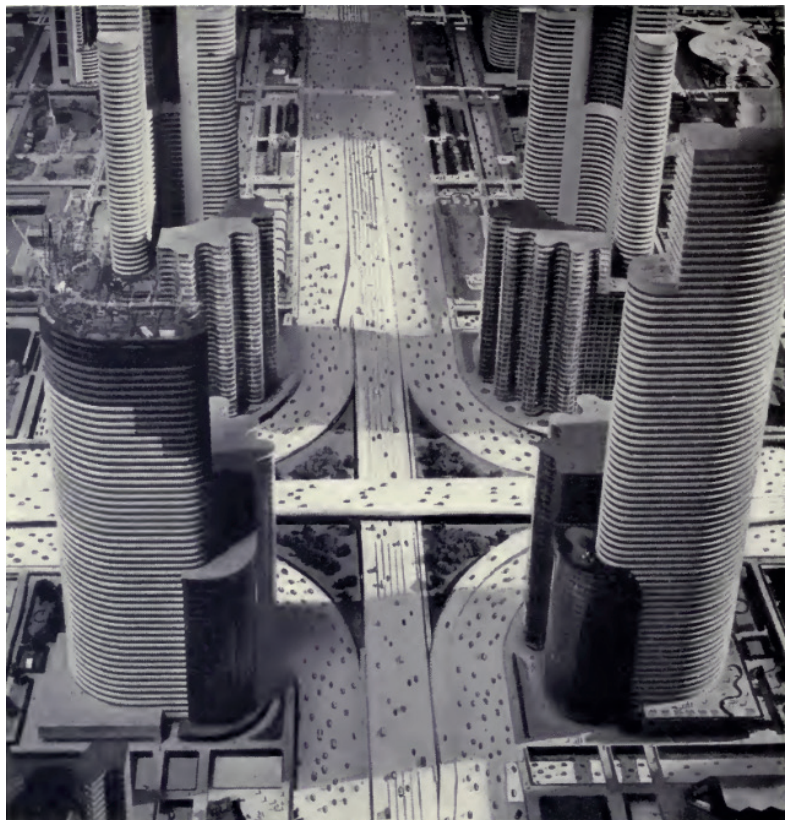

Figure 6 Express boulevards are the main arteries for the through city traffic [27]

the Futurama concept - even though it is quite old. The hypothesis is that autonomous vehicles alone cannot solve the traffic congestion problems. 


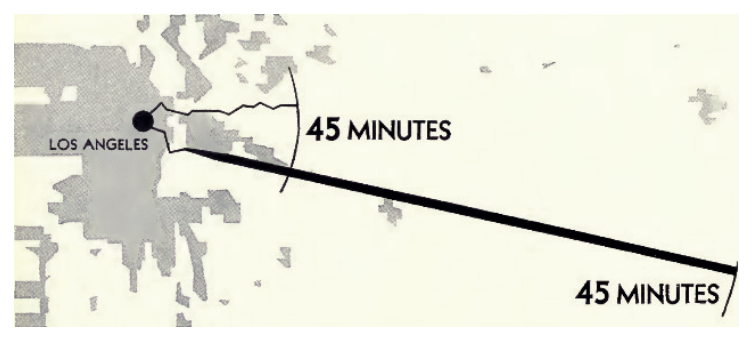

Figure 7 Commuting radius extension

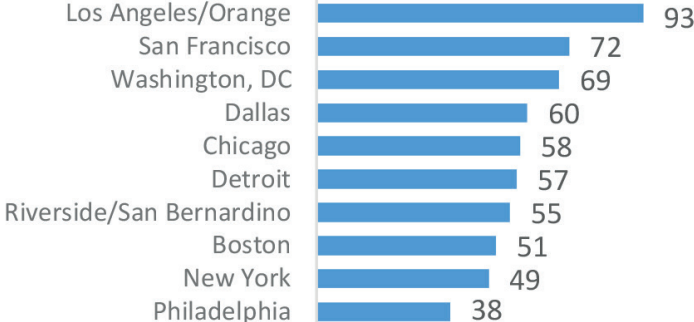

Figure 9 Annual hours of delay per Traveler by Metropolitan Area, 2003 [30]

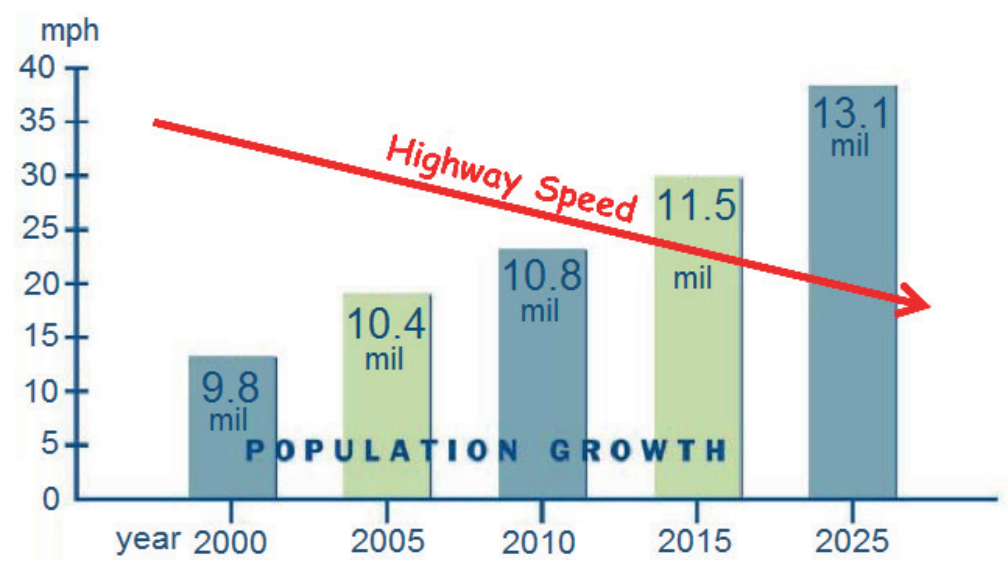

Figure 8 Comparison of population growth and highway speed [28]

\section{The Futurama concept}

In 1939, a new approach was presented in connection with transportation at the New York World's Fair [25-27]. The expo's aim was to predict the trends of the next 20 years. One of the main sponsors of the event was General Motors Corporation. Norman Bel Geddes collected his thoughts about this future in a book [27]. He saw the future in automation. One of the main reasons was to avoid accidents (Figure 1). This is still the core basis of autonomous development.

In this book, the answer for the safety, comfort, speed and economy questions was the concept of highways in and out of cities. The concept of changing between different travel speeds is depicted in Figure 2.

The identified core problem was the change (decrease) of number of lanes, which caused a bottleneck effect (Figure 3).

The connection concept of the smaller cities was the following (Figure 4).

In the case of bigger cities, the following model was proposed (Figure 5).

Image of the city center is presented in Figure 6.

A prediction for the commuter traffic was that the commuting radius can extend 6 times with this concept (Figure 7).

\section{The effect of the Futurama}

This concept had the most impact on the city of Los Angeles (LA). Therefore, the transportation changes are summarized according to the Futurama with the history of LA.

The Transportation Research Library \& Archive made a great collection of the milestones of the developments of transportation in LA [28].

The milestones, according to Barrett, were the following: in 1870s, a horse-drawn system was installed in the city. In the next decade, cable cars replaced the horse power, which was needed due to the rapid growth of the population and transit. This system was highly unreliable because of the dirt in the cable tubes, which caused freezing during operation. Therefore, this system was changed in the 1890 s to electrically powered cars. This caused a rapid expand in the network.

Some decades later, a slow degradation was starting. The principles of business started to change before and after the Second World War. The maintenance costs of the network - such as the replacement of old vehicles, the renewal of the stations and tracks - became a priority problem to the local and federal governments. The fares were artificially kept low due to political interests. Additionally, the car became a status symbol. Moreover, General Motors began to sell air-conditioned and airsuspensioned buses with 45 seats. Operators predicted that the freeway system would accommodate and speed up the buses. As a result of these processes, the last rail line was closed in 1963.

In the following decades, the bus was the core of public transport although a public discussion focused on a monorail and metro system. Those times were also characterized by innovative and special solutions that were intended to sustain public transport without a high capacity 
Table 1 Modal-split in 2005 in Los Angeles [30]

\begin{tabular}{cccc} 
Subject & Total & Male & Female \\
Workers 16 years and over & $1,662,238$ & 954,410 & 707,828 \\
MEANS OF TRANSPORTATION TO WORK & & $77.50 \%$ \\
Car, truck or van & $79.50 \%$ & $81.00 \%$ & $66.40 \%$ \\
Drove alone & $67.80 \%$ & $68.90 \%$ & $11.10 \%$ \\
Carpooled & $11.70 \%$ & $12.10 \%$ & $8.70 \%$ \\
In 2-person carpool & $9.00 \%$ & $9.20 \%$ & $1.50 \%$ \\
In 3-person carpool & $1.70 \%$ & $1.90 \%$ & $0.90 \%$ \\
In 4-or-more person carpool & $0.90 \%$ & $1.00 \%$ & 1.4 \\
Workers per car, truck or van & 1.37 & 1.34 & $11.70 \%$ \\
Public transportation (excluding taxicab) & $10.30 \%$ & $9.30 \%$ & $3.50 \%$ \\
Walked & $3.20 \%$ & $2.90 \%$ & $0.20 \%$ \\
Bicycle & $0.60 \%$ & $0.90 \%$ & $1.50 \%$ \\
Taxicab, motorcycle, or other means & $1.70 \%$ & $4.80 \%$ & $5.70 \%$ \\
\hline
\end{tabular}

Table 2 Fleet size for different TaxiBot and AutoVot scenarios (\% of current Lisbon car fleet, 24-hour weekday average) [33]

\begin{tabular}{|c|c|c|c|c|}
\hline & & & $\begin{array}{c}\text { Fleet } \\
\text { size }\end{array}$ & $\begin{array}{c}\% \text { of } \\
\text { baseline }\end{array}$ \\
\hline & & Baseline & 203000 & \\
\hline \multirow{4}{*}{$\begin{array}{l}100 \% \text { shared } \\
\text { self-driving fleet }\end{array}$} & \multirow{2}{*}{$\begin{array}{l}\text { Ride sharing } \\
\text { (TaxiBot) }\end{array}$} & No high-capacity public transport & 25917 & 12.8 \\
\hline & & With high-capacity public transport & 21120 & 10.4 \\
\hline & \multirow{2}{*}{$\begin{array}{l}\text { Car sharing } \\
\text { (AutoVot) }\end{array}$} & No high-capacity public transport & 46249 & 22.8 \\
\hline & & With high-capacity public transport & 34082 & 16.8 \\
\hline \multirow{4}{*}{$\begin{array}{l}50 \% \text { private car use } \\
\text { for motorized trips }\end{array}$} & \multirow{2}{*}{$\begin{array}{l}\text { Ride sharing } \\
\text { (TaxiBot) }\end{array}$} & No high-capacity public transport & $13265+194537^{*}$ & 102.4 \\
\hline & & With high-capacity public transport & $10900+147767^{*}$ & 78.2 \\
\hline & \multirow{2}{*}{$\begin{array}{l}\text { Car sharing } \\
\text { (AutoVot) }\end{array}$} & No high-capacity public transport & $22887+194275^{*}$ & 107.0 \\
\hline & & With high-capacity public transport & $18358+148050^{*}$ & 82.0 \\
\hline
\end{tabular}

* = shared + private cars

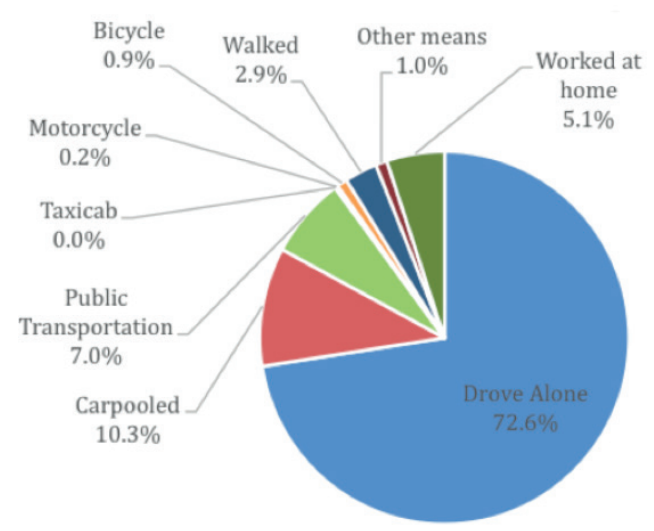

Figure 10 Modal-split in 2015 in Los Angeles [31]

core network. After several public vote fails, the first high capacity light rail line was opened in 1990 [29] and since then the network has been rapidly expanding.

Due to the high mobility and motorization, the highway speed was constantly decreasing along with the population growth (Figure 8) and the time spent in traffic jams was also increasing (Figure 9).

In 2005, a Census was made and data was also evaluated in connection with transportation (Table 1). Ten 


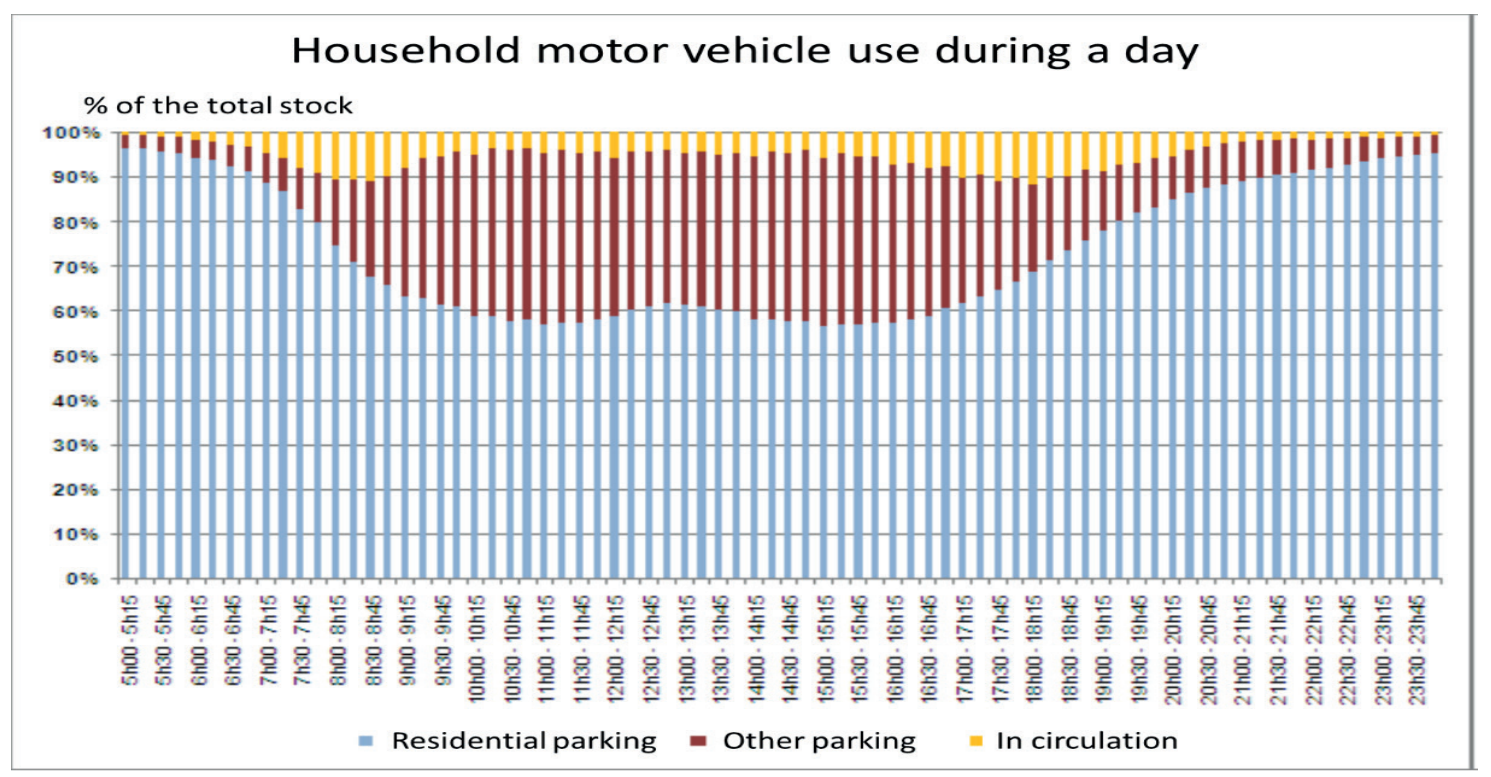

Figure 11 An average car is parked approximately 23 hours a day [32]

Table 3 The Automated levels for driving (SAE 2014) [19]

\begin{tabular}{|c|c|c|c|c|c|c|}
\hline & $\begin{array}{l}\text { SAE } \\
\text { level }\end{array}$ & Name & $\begin{array}{l}\text { Execution of steering } \\
\text { and acceleration / } \\
\text { deceleration }\end{array}$ & $\begin{array}{l}\text { Monitoring } \\
\text { of driving } \\
\text { environment }\end{array}$ & $\begin{array}{c}\text { Fallback } \\
\text { performance of } \\
\text { dynamic driving } \\
\text { task }\end{array}$ & $\begin{array}{c}\text { System capability } \\
\text { (driving modes) }\end{array}$ \\
\hline \multirow{3}{*}{$\begin{array}{l}\text { Human driver } \\
\text { monitors } \\
\text { the driving } \\
\text { environment }\end{array}$} & 0 & No automation & Human driver & Human driver & Human driver & $\mathrm{n} / \mathrm{a}$ \\
\hline & 1 & Driver assistant & $\begin{array}{l}\text { Human driver and } \\
\text { system }\end{array}$ & Human driver & Human driver & $\begin{array}{l}\text { Some driving } \\
\text { modes }\end{array}$ \\
\hline & 2 & $\begin{array}{c}\text { Partial } \\
\text { automation }\end{array}$ & System & Human driver & Human driver & $\begin{array}{l}\text { Some driving } \\
\text { modes }\end{array}$ \\
\hline \multirow{3}{*}{$\begin{array}{l}\text { Automated } \\
\text { driving system } \\
\text { monitors } \\
\text { the driving } \\
\text { environment }\end{array}$} & 3 & $\begin{array}{l}\text { Conditional } \\
\text { automation }\end{array}$ & System & System & Human driver & $\begin{array}{l}\text { Some driving } \\
\text { modes }\end{array}$ \\
\hline & 4 & High automation & System & System & System & $\begin{array}{l}\text { Some driving } \\
\text { modes }\end{array}$ \\
\hline & 5 & Full automation & System & System & System & All driving modes \\
\hline
\end{tabular}

Table 4 Possible autonomous vehicle usage [19]

\begin{tabular}{|c|c|c|c|}
\hline & Advantages & Disadvantages & Potential group of users \\
\hline $\begin{array}{l}\text { Personal autonomous vehicles } \\
\text { - self-driving vehicles in private } \\
\text { ownership. }\end{array}$ & $\begin{array}{l}\text { Continuous availability. The } \\
\text { private property can be stored } \\
\text { in the vehicle. }\end{array}$ & $\begin{array}{l}\text { A vehicle that meets the travel } \\
\text { aim cannot be chosen for each } \\
\text { trip. High costs. }\end{array}$ & $\begin{array}{l}\text { Frequent travelers on a daily } \\
\text { base, and/or the car is used as } \\
\text { a storage for private property. }\end{array}$ \\
\hline $\begin{array}{l}\text { Shared autonomous vehicles - } \\
\text { Self-driving taxis, door-to-door } \\
\text { service for the users. }\end{array}$ & $\begin{array}{l}\text { A vehicle for the actual need } \\
\text { can be chosen. Door-to-door } \\
\text { service. }\end{array}$ & $\begin{array}{l}\text { Waiting for a car is possible. } \\
\text { No personal staff (driver). } \\
\text { The car can be dirty after the } \\
\text { previous user. }\end{array}$ & Not so frequent travelers. \\
\hline $\begin{array}{l}\text { Shared autonomous rides } \\
\text { - Self-driving vans (micro- } \\
\text { transit) take passengers } \\
\text { to or near destinations. } \\
\text { Supplementary service for } \\
\text { public transport systems. }\end{array}$ & $\begin{array}{c}\text { The cost will probably be the } \\
\text { lowest. }\end{array}$ & $\begin{array}{l}\text { The comfort level will be the } \\
\text { lowest, the travel time probably } \\
\text { will be higher. }\end{array}$ & Occasional trips. \\
\hline
\end{tabular}

years later, driving alone was getting more common (Figure $10)$.

The Futurama concept had the highest impact on the transportation methods of the USA, but the rest of the word was also concerned. A survey was made about the daily car usage in Paris (Figure 11). 

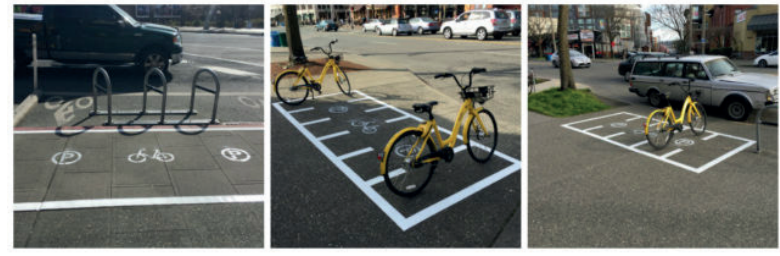

Figure 12 In Seattle, parking spaces were designated for dockless bikes [34]

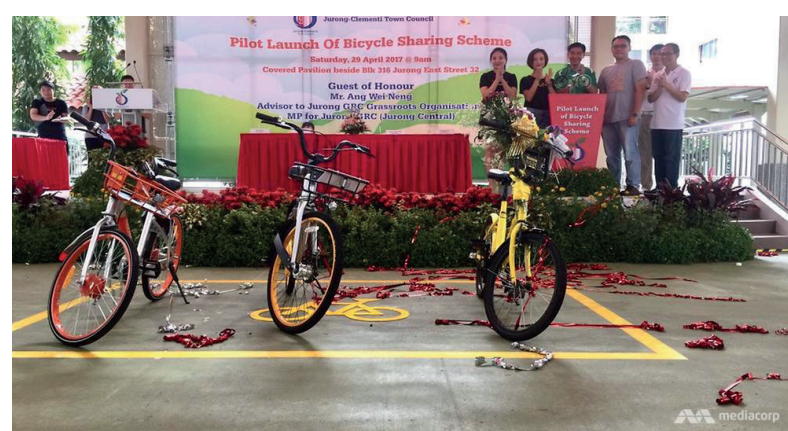

Figure 13 Singapore is still improving its dockless bike-sharing regulation [35]

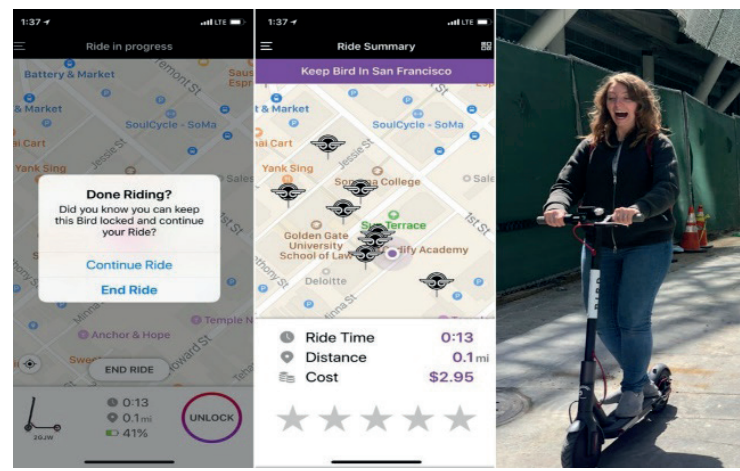

Figure 14 Bird electric scooters are taking over San Francisco [36]

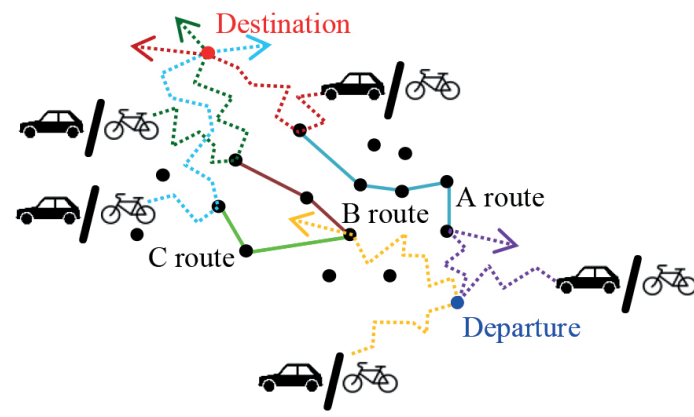

Figure 15 Traditional public transport with the new age solution

Based on this survey, only $10 \%$ of the vehicles are in the traffic flow in peak hours and $90 \%$ are parking mainly at home or other locations, especially at the working place.

According to this, only $10 \%$ of the cars are causing the traffic jams. In 2015, the International Transportation Forum published a report about the shared self-driving cars [33]. This study was based on experiences of the Autonomous taxi system for New Jersey and the taxi

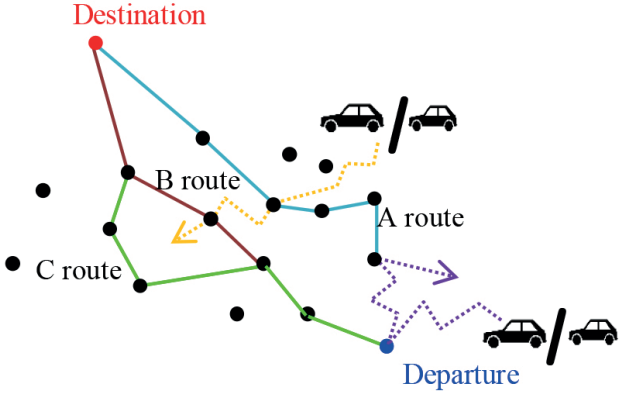

Figure 16 Traditional public transport with the new age solution during the trip

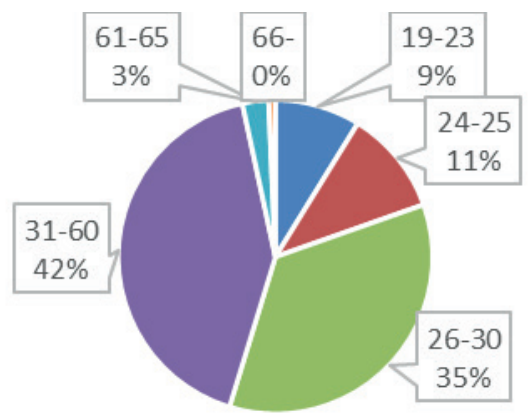

Figure 17 Age distribution

\section{Importance of punctuality}

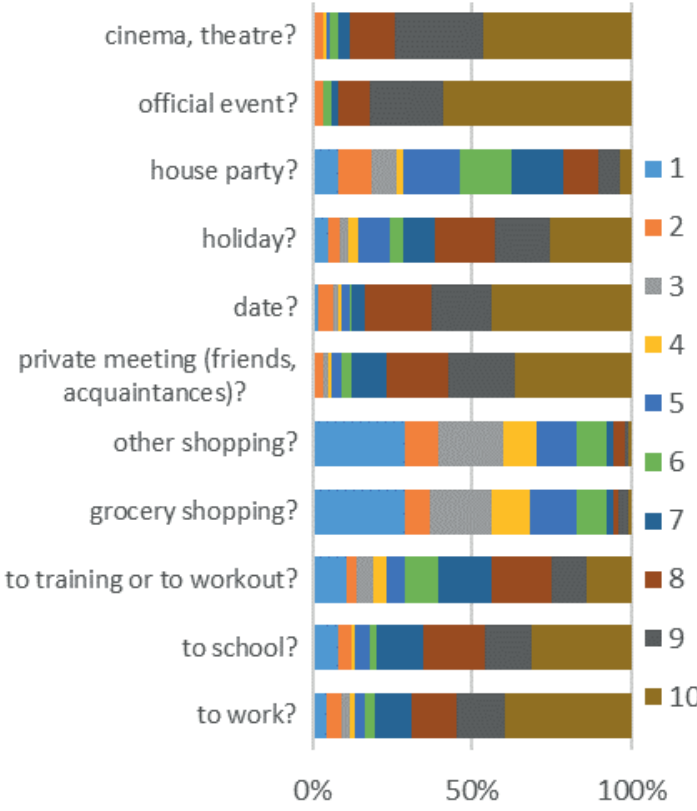

Figure 18 Importance of punctuality

pooling for New York City. The subject of the research was the city of Lisbon.

Based on Table 2, in the case of the $100 \%$ shared selfdriving fleet with a high-capacity public transport, the actual car fleet size can be reduced by $90 \%$. In the light of the car usage survey [32], this - in general - can cause elimination of the actually not used (parking) cars, but there will be no significant effect on traffic jams and road capacity. Based on 
Table 5 Employment status

\begin{tabular}{lr}
\hline Status & Percent \\
\hline Employee & $70.55 \%$ \\
Entrepreneur & $0.68 \%$ \\
Middle manager & $13.01 \%$ \\
Pensioner & $0.68 \%$ \\
Volunteer & $0.68 \%$ \\
Student and part time employee & $1.36 \%$ \\
Student & $13.01 \%$ \\
\hline
\end{tabular}

this, autonomous cars cannot replace, but only supplement the high-capacity public transport.

\section{Supplement transportation}

\subsection{Autonomous vehicles}

Definition of autonomous transport was created based on the Society of Automotive Engineers (SAE) classification [19], this is presented in Table 3 and the possible role of the car is summarized in Table 4.

According to data presented in Table 3, only level 5 is suitable for use of autonomous service.

The most effective solution for society is the shared autonomous ride that requires much less parking facilities, but the economic effect, especially for car producers, can be negative due to decrease in the number of sold cars.

\subsection{Bike, scooter share}

Traditional bike sharing systems are used worldwide nowadays. They are usually based on a fix docking network. This type of system is working properly, but it usually serves only the high density areas in the cities, if the operation costs and effectiveness are taken into consideration. Moreover, the docking stations mean a restriction for users. Therefore, some operators started to develop dockless solutions.

The greatest advantage of the dockless system is that the user can leave the bicycle anywhere. On the other hand, this can cause a mess in the cityscape. Therefore, parking places for bikes were created as a solution in Seattle (Figure 12) and in Singapore (Figure 13).

In addition to electric bikes, a new solution is underway. This is the electric scooter, which reduces the required space and gives more flexibility to the user. A service was started in San Francisco (Figure 14).

\section{Public transport and the new age transport solutions}

Considering the possible cooperation between traditional public transport, different sharing solutions and the autonomous vehicles based on the Futurama experiences and the research outcomes, it can be concluded that the public transport can only be supplemented with these solutions and cannot be fully replaced by them. Therefore, the low density areas can be served by the autonomous solution, but bike and scooter sharing systems are the best solutions for the high density city center. A schematic model is created to demonstrate this (Figure 15).

Those solutions cannot be used only to take the so-called last mile, but also to change between the high capacity transportation lines (Figure 16).

In this case, the autonomous vehicle operates as a taxi and the bike/scooter sharing system as a dockless solution.

\section{Survey data}

In 2017, a preliminary survey was made to examine the people's relationship with travelling. This survey distinguished between commuters and those going on leisure trips. A part of the results is published in another article [37]. The aim of this survey was to measure the effect of different factors on the user decisions according to the travel mode and the route planning. Due to the preliminary nature of the survey, the outcome was not representative. In order to complete the survey, one required internet connection and the questionnaires were shared via e-mail and Facebook. Even so, 146 participants submitted their answers. Those were basically submitted from Budapest and respondents were mainly people with higher education. Regarding the research of Smith [38] and the Pew Research Center [39], the spread of smartphones and internet usage are higher where the population density and the per capita income are higher. Based on this, the probability of the new techniques (e.g.: autonomous car, shared economy, ...) usage is higher. Moreover, the commuting and traffic problems appearance is presumably higher, as well. Based on this, result of this survey can be used as good preliminary data for further research. The age distribution of the respondents is presented in Figure 17.

The participants' employment status is given in Table 5 .

Regarding the data presented in Figure 9, the importance of punctuality could have a significant role, which helps to understand the effect of delay on travelers. The following diagram summarizes the results regarding punctuality (Figure 18). 
In this diagram, "1" represents the least important and "10" represents the most important factor. It clearly demonstrates that punctuality is a key factor if the event's starting time is fixed, and it is not as important in the case of categories concerning leisure time. In the light of the traffic distribution (Figure 11) and delays (Figure 9) caused by traffic jams, the predictability of commuting is of great importance.

\section{Summary}

In this article, the Futurama concept and its effect to the world (with the example of Los Angeles) were summarized. The history of LA's public transport is presented in more detail.

Two important researches were presented in connection with autonomous cars. The outcome of a survey made in Paris on distribution of car usage showed that only $10 \%$ of the cars are causing the traffic jams. Another research on autonomous car usage was based on a simulation of Lisbon's traffic change in the case of presence of autonomous taxis; this study predicted that the number of cars can be reduced to approximately $10 \%$, only if there is a well-functioning, high-capacity public transport. Based on this finding, autonomous transportation cannot replace the traditional public transport systems, it can only supplement them.

Classification of the autonomous systems was also done. Furthermore, the new age bike sharing systems were introduced. These also might have a significant effect on public transport systems and autonomous transportation.

Based on the presented survey data, punctuality is a key factor for travelers. Regarding the delays, caused by the traffic jams and the research data, the autonomous car cannot be the only solution for traffic problems. Based on this, the hypothesis of the article is considered to be supported.

This overview can be a good starting point for future research. As a next step, the routing algorithm needs to be implemented as described in Section 5.

\section{References}

[1] Tesla, Inc. [online]. [Viewed 2018-03-18]. Available from: https://www.tesla.com

[2] Alphabet Inc. Waymo - Google - Waymo [online]. [Viewed 2018-03-18]. Available from: https://www.google.com/selfdrivingcar/

[3] VAN LEIJEN, M. First fully autonomous train ride in Australia. RailFreight.com [online]. 2017. Available from: https://www.railfreight.com/business/2017/10/05/first-fully-autonomous-train-ride-in-australia/

[4] PARK, K. Airbus looking forward to a pilotless future [online]. New York: Bloomberg - Technology L.P., 2017. Available from: https://www.bloomberg.com/news/articles/2017-11-21/airbus-exploring-single-pilot-autonomous-aircraft-in-techrace

[5] LEITNER, B., REHAK, D., KERSYS, R. The new procedure for identification of infrastructure elements significance in sub-sector railway transport. Communications - Scientific Letters of the University of Zilina [online]. 2018, 20(2), p. 41-48. ISSN 2585-7878, eISSN 2585-7878. Available from: http://komunikacie.uniza.sk/index.php/communications/article/view/86

[6] COCCHIA, A. Smart and digital city: a systematic literature review [online]. In: Smart city: how to create public and economic value with high technology in urban space. DAMERI, R. P., ROSENTHAL-SABROUX, C. (eds.). Cham: Springer, 2014, p. 13-43. Available from: https://doi.org/10.1007/978-3-319-06160-3_2

[7] KORYAGIN, M. Urban planning: a game theory application for the travel demand management. Periodica Polytechnica Transportation Engineering [online]. 2018, 46(4), p. 171-178. ISSN 0303-7800, eISSN 1587-3811. Available from: https://doi.org/10.3311/PPtr.9410

[8] CZIMMERMANN, P., KOHANI, M. Characteristics of changes of transportation performance for pairs of critical edges. Communications - Scientific Letters of the University of Zilina [online]. 2018, 20(3), p. 84-87. ISSN 2585-7878, eISSN 2585-7878. Available from: http://komunikacie.uniza.sk/index.php/communications/article/view/258

[9] LI, Z.-CH., LAM, W. H. K., WONG, S. C., ZHU, D.-L., HUANG, H.-J. Modeling park-and-ride services in a multimodal transport network with elastic demand. Transportation Research Record Journal [online]. 2007, 1994(1994), p. 101-109. ISSN 0361-1981, eISSN 2169-4052. Available from: https://doi.org/10.3141/1994-14

[10] KIRCHLER, D. Efficient routing on multi-modal transportation networks. Data Structures and Algorithms [cs.DS] [online]. Paris: Ecole Polytechnique X, 2013. Available from: https://pastel.archives-ouvertes.fr/pastel-00877450

[11] RUDOLPH, F., MATRAI, T. Congestion from a multimodal perspective. Periodica Polytechnica Transportation Engineering [online]. 2018, 46(4), p. 215-221. ISSN 0303-7800, eISSN 1587-3811. Available from: https://doi.org/10.3311/PPtr.12048

[12] NOREIKIS, M., BUTKUS, P., NURMINEN, J. K. In-vehicle application for multimodal route planning and analysis. Aalto, Finland: Aalto University, 2014. 
[13] MORFOUlaKI, M., KOTOULA, K. M., MYROVALI, G., AIFADOPOULOU, G. Calculating the impacts of alternative parking pricing and enforcement policies in urban areas with traffic problems. Periodica Polytechnica Transportation Engineering [online]. 2017, 45(1), p. 35-41. ISSN 0303-7800, eISSN 1587-3811. Available from: https://doi.org/10.3311/PPtr.9099

[14] HYKS, O., NEUBERGOVA, K., PRIBYL, P. Influence of driving fluency on economic and ecological aspects of transport. Communications - Scientific Letters of the University of Zilina [online]. 2018, 20(3), p. 9-14. ISSN 2585-7878, eISSN 2585-7878. Available from: http://komunikacie.uniza.sk/index.php/communications/article/view/245

[15] PAWESKA, M., RISTVEJ, J. Logistics during population and animals evacuation in case of extraordinary incidents and crisis events. Communications - Scientific Letters of the University of Zilina [online]. 2018, 20(2), p. 88-95. ISSN 2585-7878, eISSN 2585-7878. Available from: http://komunikacie.uniza.sk/index.php/communications/article/view/93

[16] SCHOETTLE, B., SIVAK, M. A survey of public opinion about autonomous and self-driving vehicles in the U.S., the U.K., and Australia. Ann Arbor, Michigan, USA: University of Michigan, Transportation Research Institute, 2014.

[17] LIN, P. Why Ethics matters for autonomous cars [online]. In: Autonomous driving. MAURER, M., GERDES J., LENZ B., WINNER H. (eds.). Berlin, Heidelberg: Springer, 2016, p. 69-85. ISBN 978-3-662-48845-4, eISBN 978-3-662-48847-8. Available from: https://doi.org/ 10.1007/978-3-662-48847-8_4

[18] SZALAY, Z., NYERGES, A., HAMAR, Z., HESZ, M. Technical specification methodology for an automotive proving ground dedicated to connected and automated vehicles. Periodica Polytechnica Transportation Engineering [online]. 2017, 45(3), p. 168-174. ISSN 0303-7800, eISSN 1587-3811. Available from: https://doi.org/10.3311/PPtr.10708

[19] LITMAN, T. Autonomous vehicle implementation predictions - implications for transport planning. Victoria, Canada: Victoria Transport Policy Institute, 2018.

[20] KPMG. Impact of autonomous vehicles on public transport sector. Swiss: KPMG International Cooperative, 2017.

[21] PAUER, G., TOROK, A. Static system optimum of linear traffic distribution problem assuming an intelligent and autonomous transportation system. Periodica Polytechnica Transportation Engineering [online]. 2018, 47(1), p. 64-67. ISSN 0303-7800, eISSN 1587-3811. Available from: https://doi.org/10.3311/PPtr.11548

[22] SAIF, M. A., ZEFREH, M. M., TOROK, A. Public transport accessibility: a literature review. Periodica Polytechnica Transportation Engineering [online]. 2018, 47(1), p. 36-43. ISSN 0303-7800, eISSN 1587-3811. Available from: https://doi.org/10.3311/PPtr.12072

[23] KATONA, G., JUHASZ, J. Autonomous cars in a multimodal transport plan. Zielona Gora: University of Zielona Gora, 2018. ISBN 978-83-945647-1-1.

[24] VITEZY, D. A jovo varosanak kozlekedese: veszelyek es lehetosegek / Transport for the city of the future: dangers and opportunities (in Hungarian). 2018.

[25] FOX, R. W., LEARS, T. J. J. The power of culture: critical essays in American history. Chicago: The University of Chicago Press Ltd., 1993. ISBN 0-226-25955-2.

[26] Handy (Jam) Organization - To new horizons [online]. Available from: https://archive.org/details/ToNewHor1940

[27] GEDDES, N. B. Magic motorways. New York: Random House, 1940.

[28] BARRETT, M. Los Angeles transportation transit history - South LA. Los Angeles: 2014.

[29] Metro (the Los Angeles County Metropolitan Transportation Authority) - 20 years of metro rail [online]. [Viewed 201808-29]. Available from: https://www.metro.net/about/about-metro/

[30] The Public Information Office of the Department of Transportation. The city of Los Angeles transportation profile 2009 [online]. Los Angeles: City of Los Angeles Department of Transportation, 2009. Available from: https://handels.gu.se/digitalAssets/1344/1344071_city-of-la-transportation-profile.pdf

[31] Shared-Use Mobility Center (SUMC). Los Angeles county - shared mobility action plan. Chicago: Shared-Use Mobility Center (SUMC), 2016.

[32] SCHMITT, D. Motorisation et usage de la voiture en Ile-de-France. Enquete globale transport / Motorization and car usage in the Ile-de-France. Global transport survey (in French). Paris: Direction regionale et interdepartementale de l'Equipement et de l'Amenagement (DRIEA) d'ile-de-France Service de la Connaissance des Etudes el de la Prospective, 2013.

[33] International Transportation Forum - Corporate Partnership Board. Urban mobility system upgrade - how shared selfdriving cars could change city traffic. Paris: International Transport Forum at the OECD, 2015.

[34] COX, S. Seattle tries designated parking for dockless bikes [online]. Better Bike Share Partnership, 2018. Available from: http://betterbikeshare.org/2018/04/25/seattle-tries-designated-parking-dockless-bikes/

[35] GAUQUELIN, A. Singapore is still improving its dockless bike-share regulation [online]. Bikeshare News, 2018. Available from: http://www.bikeshare-news.com/2018/03/05/singapore-is-still-improving-its-dockless-bike-shareregulation/

[36] Robinson, M. A startup in the West Coast scooter sharing craze is already worth \$1 billion here's what it's like to ride a Bird scooter [online]. Business Insider Inc., 2018. Available from: https://www.businessinsider.com/bird-electric-scooter-review-2018-4 
[37] KATONA, G., JUHASZ, J. User habits and multimodal route planning. Production Engineering Archives / Archiwum Inzynierii Produkcji. 2017, 16, p. 22-27. ISSN 2353-5156, eISSN 2353-7779.

[38] SMITH, A. Smartphone ownership - 2013 update [online]. Washington, D. C: Pew Research Center's Internet \& American Life Project, 2013. Available from: https://www.pewinternet.org/2013/06/05/smartphone-ownership-2013/

[39] POUSHTER, J. Smartphone ownership and internet usage continues to climb in emerging economies [online]. Pew Research Centre, 2016. Available from: https://www.pewresearch.org/global/2016/02/22/smartphone-ownership-andinternet-usage-continues-to-climb-in-emerging-economies/

[40] Futurama (New York World's Fair) - Wikipedia [online]. [Viewed 2018-08-26]. Available from: https://en.wikipedia.org/wiki/Futurama_(New_York_World\%27s_Fair) 